\title{
МЕДИЕВИСТИЧКА ПРОУЧАВАЊА АНАТОЛИЈА АРКАДИЈЕВИЧА ТУРИЛОВА
}

(Анатолиј А. Турилов, Источници српског средюег века, са руског језика превели Татјана Суботин Голубовић, Василије Стоиљковић и Татјана Вулетић, Међународни центар за православне студије, Центар за византијско-словенске студије Универзитета у Нишу, Ниш, 2020)

Иностраног члана Српске академије наука и уметности, Анатолија Аркадијевича Турилова ${ }^{1}$, са Србијом и српском историјом најпре веже интересовање за, у најширем смислу, српско средњовековље. Иза изузетне упућености у српску медиевистику стоји свестрано образовање руског научника. Након завршених основних студија на Ломоносовљевом универзитету у Москви, А. Турилов уписује магистратуру на Институту за славистику и балканистику Академије наука СССР, где брани магистарску тезу на тему бугарских и српских извора за средњовековну историју Балкана у руској писмености. Касније специјализира из области духовне културе православних Словена средњег века и раног новог века, средњовековне словенске писмене традиције и науке о изворима за проучавање историје. Дугогодишњи научни рад и посвећеност поменутим темама и бројним подтемама које из њих извиру, Турилова чине великим познаваоцем словенских питања, а у окиру њих - посебно јужнословенских, те он постаје изузетна научна фигура када је реч о изучавању славистике. Јужнословенско средњовековље пак није био његов првобитни научни позив, већ се на Историјском факултету Универзитета у Москви, како се из његових интервјуа сазнаје, на часовима палеографије родило интересовање ка проучавању старе руске рукописне књиге. Почетно ин-

1 Анатолиј Аркадијевич Турилов је рођен 23. маја 1951. године у Јарослављу (граду 280 километара северно од Москве). [...] Био је члан Комисије за рукописе при Међународном информационом центру за изучавање извора за историју Балкана и Средоземља (CIBAL) у периоду 1984-1994, Међународне библијске комисије при Међународном комитету слависта (до 2013). Члан је Археографске комисије РАН, Научно-издавачког савета Православне енциклопедије, Експертског савета за доделу награде у част митрополита Макарија (Булгакова), научног већа Државних музеја Московског Кремља, Међународног центра за православне студије из Ниша, Националног комитета слависта (од 2018), Комисије за доделу награде у част Алексеја Александровича Шахматова (од 1018) (TURILOV 2020: 225, 226). 
тересовање прераста у умеће, те он данас јесте један од водећих руских и светских археографа старих словенских ћириличних рукописа. Љубав према руским рукописима даље га је неупитно водила ка руско-јужнословенским односима, док је велики изазов за руског научника било конкретно проматрање руско-српских културних веза. Како је познато у теорији, руско-српске културне везе имају вишевековну историју, почевши од средњег века. Међутим, сведочанства о томе заиста су малобројна. Одсуство опипљивих докумената за Турилова само је представљало научни изазов, те он често и инсистира на посредном и индиректном карактеру руско-српских веза из којег црпи највећи могући истраживачки потенцијал.

Из оваквог образовног пута и дугогодишње посвећености и радозналости, А. Турилов артикикулише научну мисао и ка проучавању само, као што смо на почетку истакли, српског средњег века. У томе је изузетно успешан, те заслужено постаје један од најзначајнијих проучавалаца српске медиевистике. Теме које обрађује у својим студијама, есејима, освртима и приказима бројне су и разнолике. Интересовање ка српској средњовековној писаној традицији изродило је бројне радове који се тичу проучавања споменика и српске рукописне заоставштине, из чега се гранају инспиративна питања и проблеми. Руски научник у својим истраживањима остаје веран проучавању руско-српских културних веза, али исто тако поље компаративног проматрања шири и на руско-бугарске односе, бугарско-српско-руске, али у оквиру поменутих тема, инкорпорира и рукописно наслеђе са простора Македоније, те у том смислу гради једно православно словенско заједништво. Неке од студија посвећене су и српско-грчком односу и везама. Ипак, Турилов најчешће апострофира изразити значај српске рукописне заоставштине. У разговору који је са њим водио Зоран Хр. Радисављевић, за лист Политика, 2012. године, руски научник истиче да је српска рукописна традиција, најпре, отворена за дела и преводе настале у другим словенским земљама и, у том погледу, она је блиска руској, док је бугарска далеко затворенија и усредсређенија на саму себе. Турилов поменути значај налази и у конзерватизму, јер после смењивања црквених типика у XIV веку и појаве нових превода у Србији није дошло до масовног искључивања из круга штива старијих дела, како оригиналних, тако и преводних. Напослетку, он истиче да су „српски рукописи често незамењив извор за проучавање не само српске оригиналне књижевности, него и најстарије књижевне традиције Ћирила и Методија из IX и X века и бугарске књижевности од XI до XIV [...]” (TURILOV 2017: 31).

Српска академска заједница подробније се упознала са овим руским научником, ако не раније, онда бар 2016. године када је у Београду, заједно са Људмилом Мошковом, објавио друго, допуњено издање Каталога словенских рукописа Светогорских манастира. Рукописи српске 
редакције јесу већина у поменутом каталогу, те је издавање у српској престоници било, како и сами аутори истичу, сасвим логично и природно.

На велику радост проучавалаца средњег века, 2020. година доноси још једну књигу овог угледног научника, објављену на српском језику. У издању Међународног центра за православне студије и Центра за византијско-словенске студије Универзитета у Нишу, изашла је књига са изабраним радовима А. А. Турилова - Источници српског средюег века. Књига је објављена у оквиру издавачког плана Међународне научне мреже Pax Byzantino-Slava, уредника проф. др Драгише Бојовића и доц. др Јелене Стошић, а текстове су са руског превели проф. др Татјана Суботин Голубовић, Василије Стоиљковић и Татјана Вулетић. У питању су радови који, како аутор у Предговору истиче, писани од деведесетих година прошлог до почетка друге деценије овог века. Мноштво је занимљивих тема, почевши од књижевних и културних веза словенских народа, преко разматрања питања која имају везе са јунацима српске историје - Светим Савом, Марком Краљевићем, Милошем Обилићем, Вуком Бранковићем и Стефаном Лазаревићем, све до повести о Хиландару и његовим светињама.

Први чланак који се нашао у књизи јесте „Улога српске традиције у чувању најстаријих споменика словенске књижевности”. У уводу рада, Турилов апострофира значај династије Немањића, истичући да је у доба светородне лозе Србија и званично ушла у православно-византијски ареал. Како српска традиција почива на немањићким темељима, долази се до тезе да је српска књижевна традиција ризница словенских књижевних споменика. Симеона и Саву, као прве српске учитеље, аутор пореди са Ћирилом и Методијем. Преписи Саве и његових ученика, утемељили су језичко-православну стабилност, а немањићка политичка стабилност утицала је на књижевну - на развијање и чување културних традиција. У контексту чувања српске књижевне културе, истиче се значај Хиландара и библиотеке тог манастира као најрепрезентативније јужнословенске традиције. У ризницу словенских књижевних текстова које аутор подразумева, укључују се оригинални текстови, преводи и компилације најразличитијег обима, а сви они јесу сачувани захваљујући српској традицији. Уопште узев, главна нит рада јесте улога српске рукописне традиције XIII и XIV века у очувању најстаријих споменика словенских књижевности насталих у IX-X веку у Бугарској и Великој Моравској.

Следећа обрађена тема јесте прилично широка: „Српска средњовековна литерарно-књижевна традиција у контексту православног словенског заједништва на Балкану". Турилов наговештава да ће саопштење имати карактер прегледног излагања материје. Аутор најпре образлаже феномене који карактеришу и обједињују књижевност Slavia Orthodoxa, а у оквиру тога разматра компоненте наднационалне књижевности (књижевни слој-посредник) и националне. Национална књижевност је најма- 
ње покретљива, житија, међутим, добијају општебалкански карактер.

Значај српске средњовековне књижевне традиције у оквиру јужнословенске је изузетан, а када је реч о најстаријим словенским споменицима, управо је српска писменост обезбеђивала њихово очување током векова.

Рад под називом „Културне везе Московске Русије и Србије” најопширнији је у књизи Источници српског средюег века, те ћемо се на њега и најдетаљније осврнути. У питању је ширина тема и ширина веза које аутор обухвата. Није реч само о културним, већ и историјским, књижевним и политичким спонама. Пишући о поменутим везама Московске Русије и Србије, аутор то заиста чини на систематичан начин - концизан, истовремено и темељан. Као временски оквир разматрања поменутог односа узет је период од последње четвртине XIV до XVII века. Историјске, културне и политичке околности које су се кроз векове смењивале у обе земље, диктирале су различиту динамику веза. Српско-руски контакти нису све време били исте јачине и интензитета, нити је начин реализације ових контаката био истоветан. Међутим, пратећи фазе културних веза које аутор разматра, примећује се да се као свеприсутна и спајајућа нит скоро увек јавља Атос. У наставку рада, прокоментарисаћемо само неке од бројних сведочанстава које је Турилов уврстио у свој преглед.

Прву половину XIV века карактеришу непосредни и незванични контакти који су се без изузетака остваривали посредством Атоса и Константинопоља, док 70-е године доносе најживље контакте Московске Русије и Јужних Словена, самим тим и Срба. Напредак у везама показаће се у раду руских писара са српским књигама. „У оквиру Стиховног пролога у Русију су, вероватно на прелазу из XIV у XV век доспела и житија најважнијих српских светаца Саве и Симеона." (TURILOV 2020: 37) Аутор нас информише и о другачијим сазнањима, не само књижевним, која су доспевала до далеке Русије. Наиме, до Москве стижу вести и писана сведочења о Косовском боју, као и о бици на реци Марици. Занимљиво, аутор у књизи преноси навод драматичног описа стања у земљи после Маричке битке - текст је сачуван у предговору, или поговору (зависи од преписа) старца Исаије његовом преводу дела Псеудо Дионисија Ареопагита. Како и сам аутор закључује, заиста је невероватно да овај приказ није сачуван у српској изворној традицији, али је зато посведочен у бројним руским преписима.

Петнаести век доноси централну личност српско-руских односа: Пахомија Логотета. Аутор Пахомија доводи у везу са личношћу која је обележила XVI век - Аникитом Лавом Филологом. Пахомије Логотет, Србин који је у Русију стигао управо са Атоса, био је књижевник, али и преписивач. По свему судећи, реч је о загонетној личности, јер се о српском и светогорском периоду његовог живота ништа не зна. Како аутор истиче, Пахомије је, без преувеличавања створио целу једну књижев- 
ност, написавши више него скоро сви његови руски савременици заједно. Иновативност коју је Пахомије унео у руску књижевност, тачније, у химнографију, јесте акростих, док је Пахомијево стваралаштво одиграло је велику улогу у прихватању реторског стила „плетенија словес” у Русији. Са друге стране, Аникита Лав Филолог је, као и Пахомије, био светогорски монах и неко време је живео у Русији. За разлику од Пахомија, Филолог се, после боравка у Русији, вратио на Атос. Вест о још једном српском писцу који је у XVI веку стварао у Русији и за Русију сачувала се у заглављу канона Варлааму Хутинском, а у зборнику с краја тог века аутор је означен као инок Филотеј Србин.

Крај XV века, како Турилов истиче, доноси нови систем рускосрпских односа. У том периоду Московска Русија је остала једина потпуно независна православна држава. Са друге стране, стање у Србији постаје теже и управо новонастале прилике су Москву учиниле једним од главних центара руско-српских односа. Управо тада се за помоћ упућују изасланства српских и светогорских манастира. „При томе, културне, у првом реду књижевне везе отприлике до средине XVI века и надаље у основи имају исти смер: у Москви се преписују и користе састави и преводи руских књижевника, а кретање књига и текстова у супротном правцу још увек имају малу улогу" (TURILOV 2020: 51).

Шеснаести век обележиће писање руског дела Хронограø, а од писања Хроногрофа српска житија су трајно ушла у састав руске писмености XVI, XVII века. Такође, необичан облик српско-руских спона везује се за крај XV, прву половину XVI века: Срби писари јављају се као посредници између великих кнежева московских и муслиманских владара Високе Порте.

Доба владавине Ивана Васиљевича Грозног и XVI век обележен је порастом поштовања српских светаца, у првом реду Симеона и Саве Српског и кнеза Лазара, чији су ликови били додати међу фреске саборне цркве Св. Арханђела у Кремљу, док у XVII веку и периоду династије Романових у историји руско-српских културних односа наступа нови период.

У раду „Дечански одломак 'Повести о цару Казарину”, Турилов најпре пише о средњовековној рукописној традицији, са главним освртом на фолклоризоване повести на теме из касноримске и византијске историје. Аутор ће се на занимљив начин осврнути на поглед на рукописно наслеђе из угла усмене традиције, наслеђе које је плодно тле нашло у јужнословенској књижевности.

Предмет разматрања у поменутом контексту је „Повест о цару Казарину и његовој жени”. Извршена је анализа и поређење фолклоризоване повести са историјским чињеницама. Аутор алудира на стварне историјске догађаје, идентификујући актере са стварним историјским прототиповима (Казарина поистовећује са византијским царем Јустини- 
јаном II Ринотметом, а „други цар” јесте Лав IV).

Каква је судбина овог преписа са мотивима из византијске историје? Сазнајемо да је до недавно овај текст био познат само по многобројним руским преписима из периода од последње четвртине XV до XVIII века. Аутор, међутим, указује на значајно откриће - у питању је дужи одломак у српском зборнику из треће четвртине или последње трећине XIV века из Библиотеке Дечанског манастира. Реч је о дечанском рукопису број 3, који садржи Повест о цару Казарину. Аутор пружа драгоцене информације о изледу рукописа и његовом садржају. Поред поменуте повести, аутор указује на још неколико јединствених и ретких текстова из Дечанског зборника.

Напослетку, како Турилов истиче, потпуна и прецизна реконструкија тачне историје Повести још увек није у потпуности могућа, но приложени подаци представљају изузетну основу за будућа истраживања, нарочито зато што аутор пружа могуће варијанте порекла текста, до којих је дошао на основу лексичке анализе.

Тема руско-јужнословенских веза у контексту рукописног и културног наслеђа наставља се и у раду „' Поученије Мојсеја' и Зборник игумана Спиридона”. Турилов, најпре, разматра статус новгородске Поуке из XII века, а у центру истраживања јесте српски зборник треће четвртине XIV века, у коме се налази препис поменуте Поуке. Анализом судбине преписа, аутор одговара на питање шта се дешава када се догоди рани прелазак књижевног споменика у другачије историјско, културно и књижевно окружење. Од изузетног значаја јесте упућивање на део текста који нема паралеле у досада познатим руским преписима. Аутор указује на језичке карактеристике које су изражене (лексички русизми, источнословенски регионалзми), као и на порекло лексичког слоја.

Следећи рад покреће занимљиво питање: „Које је 'многе законске књиге' 1219. преписао Свети Сава Српски?” Када је реч о потенцијалном одговору, мишљења су у научној литератури последња два века била подељена. Наиме, у Доментијановом Житију Светог Саве говори се како се новопостављени архиепископ, при повратку из Никеје у Србију, задржао у манастиру Филокал и „књиге многе преписа законске о исправљању вере, што беху потребне његовој Саборној цркви,", док, са друге стране, та епизода у Теодосијевом Житију није забележена. Неслагање истраживача јесте у могућем садржају књига законских. О томе расправљају Собољески, Владимир Ћоровић, Димитрије Калезић и др. Турилов коментарише поменуте тврдње и предлаже своју хипотезу према којој су међу многим законским књигама, поред Крмчије, биле и Пандекте Никона Црногорца, са којима се Сава могао упознати у руском манастиру на Светој Гори.

Циљ чланка под називом „Када је краљ Марко мењао жене” јесте датирање Празничног минеја из збирке А. И. Хлудова. Међу проу- 
чаваоцима, рукопис је постао познат због записа, састављеног од стране писара - дијака Добрета. Почетни део представља „више него весело сведочанство о психологији срењовековних велможа, а поготову о личности краљевића Марка”. Дијак Добре радио је „у дане благоверног краља Марка, када овај Теодору, жену Гргурову, даде Хлапену, а себи узе његову кћер своју првовенчану жену Јелену." Кренувши од веселог сведочанства Турилов озбиљно залази у историјско проматрање и у временском следу контекстуализује поменуте личности. Дакле, причом о Марковој замени жене, одређује и време настанка Хлудевског минеја.

У раду „Последњи одјек идеје 'Царства Срба и Грка' аутор анализира натпис Вука Бранковића о подизању града (1378-1379), са четири аспекта: 1) историјско-политичка позадина, 2) кодиколошки и палеографски подаци о споменику, 3) типолошка и жанровска припадност споменика и 4) значај натписа као историјског извора. Са једне стране, рад представља изузетну анализу поменутог натписа, који је сачуван у препису, док је оригинал изгубљен још у XIV веку, а са друге стране, садржина рада може да се посматра и као пут гашења идеје државе „Срба и Грка”.

Предмет интересовања овог руског аутора, даље, јесте древни реликијар из Благовештењске саборне цркве у Московском Кремљу, у коме се до прве деценије XX века чувала једна кост руке цара Константина. Дуго се споменик сматрао делом руских сребрнара, међутим у питању је реликвијар српске израде.

Турилов пише о доласку реликвијара у Русију, о специфичностима самог ковчега и шарама на њему. У циљу одређивања времена настанка реликвијара, аутор разматра графичке и правописне особености гравура богослужбених натписа на ковчегу.

У раду „Коме је јединоименан Раннокисум?” Турилов анализира глосе у тексту Константина Филозофа - Житије деспота Cтефана Лазаревићa, при чему има у виду како српске тако и руске преписе поменутог текста. У центру разматрања јесте специфично име Раннокисум, које се не може извести из словенског, али ни из грчког језика. У контексту загонетног имена, а на основу руског Волоколамског преписа, аутор доноси различите закључке.

Српски деспот Стефан Лазаревић и његово Житије значајни су и за рад под називом „Харуналрашидовски сиже у словенским књижевностима XV и XVI века". Наиме, лутајући сиже ноћних шетњи багдадског калифе Харуна ал Рашида књижевну форму добија у хагиографским текстовима. У руској хагиографији, у питању је московси кнез Иван Данилович Калита, а у српској - деспот Стефан Лазаревић. Аутор рада пореди текст из Волоколамског патерика и Житија Константина Филозофа. Излагања су веома слична, али се примарном треба сматрати српска прича. У контексту поменутог сижеа, Турилов ће искористити прилику да још једном размотри статус јужнословенског утицаја у Русији, у XVI веку, када у овој 
источнословенској држави постају познате простране редакције житија са јужнословенских простора.

Анатолиј Аркадијевич Турилов често ће истицати значај Свете Горе и њених светиња, будући да се интензивно бавио богатим рукописним наслеђем Атоса. Свету Гору сматра седиштем преписивања и превођења у средњем веку, док посебно издваја рукописну библиотеку манастира Хиландара. Овај српски православни храм у средишту је и његовог последњег рада у књизи Источници српског средњег века под називом „Приче о чудотворним иконама манастира Хиландара у руском запису из XVI века”.

Рад је специфичне структуре и почиње описом треће манастирске делегације која је са Свете Горе стигла у Москву 1558. године. Повод конкретне посете била је изградња зидова, кула и келија Хиландара, због чега је монасима била неопходна новчана помоћ из Русије. Заузврат - монаси су цару даривали поклоне, док су радо делили и приче о свом манастиру, чудотворним иконама и осталим реликвијама. Приче су, на срећу, сачуване на папиру, захваљујући непознатом руском писцу. Сведочења чланова хиландарског изасланства сачувана су само у једном препису. Аутор рада анализира и коментарише повести о следећим иконама: Евхаитска икона, икона Богородице Тројеручице, „Старачка” икона, Евнуховска икона Богородице, „Огњепаљнаја” икона арханђела Михаила. Поред овога, у препису се налазе и Чуда о маловерним и немарним монасима, а у питању је серија од девет кратких епизода, од којих су неке означене као приче члана делегације - старца Анастасија. Осим икона, такође се говорило и о манастирским реликвијама, ктиторима и дародавцима.

Богатство тема којих смо се само укратко дотакли у скромном прегледу радова Анатолија Аркадијевича Турилова показује изузетну компетентност овог аутора у оквиру проучавања српске медиевистике. Књига руског научника на српском језику -Источници српског средюег века - још један је значајан подухват у низу, када је реч о издавачкој делатности Међународног центра за православне студије и Центра за византијско-словенске студије Универзитета у Нишу. Овај, може се чак рећи - зборник радова, представља ризницу изузетних запажања, а сваки рад са собом носи мноштво хипотеза које могу бити предмет будућих истраживања. Свака студија у себи крије надахнуће за даља истраживања у области историје средњег века, али и књижевности и уметности.

Теодора Д. Бојовић Универзитет у Београду Филолошки факултет dorateab@yahoo.com 